\title{
Tissue Factor Pathway Inhibitor 2
}

National Cancer Institute

\section{Source}

National Cancer Institute. Tissue Factor Pathway Inhibitor 2. NCI Thesaurus. Code C111846.

Tissue factor pathway inhibitor 2 ( $235 \mathrm{aa}, \sim 27 \mathrm{kDa}$ ) is encoded by the human TFPI2 gene. This protein plays a role in the inhibition of serine proteinases. 